\title{
Non-Obstrüktif Azospermide Tek Taraflı Mikroskopik Testiküler Sperm Ekstraksiyonu
}

\author{
Unilateral Microscopic Testicular Sperm Extraction in Non-Obstructive Azoospermia
}

\author{
Erdem Koc', Fevzi Bedir², Ibrahim Karabulut², Isa Ozbey³, Ozkan Polat ${ }^{3}$ \\ ${ }^{1}$ Ankara Yıldırım Beyazıt University, Ankara Atatürk Training and Research Hospital, Department of Urology \\ ${ }^{2}$ Health Sciences University, Erzurum State Training and Research Hospital, Department of Urology \\ ${ }^{3}$ Erzurum Atatürk University Faculty of Medicine, Department of Urology
}

Geliş tarihi (Submitted): 16.01.2019

Kabul tarihi (Accepted): 25.04.2019

Yazışma / Correspondence

Erdem Koc, MD

ORCID: 0000-0003-3439-2105

Department of Urology, Ankara

Yildırım Beyazıt University, Ankara

Atatürk Training and Research Hospital,

Bilkent Street 3, Ankara 06800, Turkey

E-mail: drerdemkoc@gmail.com

Mobile Phone: +90 5066614366

\section{(i) (8)}

Bu eser Creative Commons AtifGayriTicari 4.0 Uluslararası Lisansı ile lisanslanmıștır.
Özet

Amaç: Çalışamızda, kliniğimizdeki nonobstrüktif azoospermi (NOA) olgularında tek taraflı mikroskobik testiküler sperm ekstraksiyonu (mTESE) sonuçlarımızı sunmayı ve başarıyı etkileyen faktörleri ortaya koymayı amaçladık.

Gereç ve Yöntemler: Çalışmamıza toplam 102 NOA hastası dahil edildi. Hastaların testis hacimleri, serum folikül uyarıcı hormon (FSH), lüteinizan hormon (LH), prolaktin (PRL) ve testosteron (T) düzeyleri ölçüldü, genetik değerlendirmeleri yapıldı. Ardından mTESE uygulanarak hastalar, sperm ekstraksiyonunun başarılı (sperm bulunan) veya başarısız (sperm bulunmayan) olmasına göre iki gruba ayrıldı. Gruplar demografik, klinik ve histopatolojik veriler açısından karşılaştırıldı.

Bulgular: mTESE ile sperm ekstraksiyonu başarı oranımız \%62.7 idi ( $\mathrm{n}=64)$. İki grup arasında yaş, infertilite süresi, serum $\mathrm{T}$ ve PRL düzeyleri açısından anlamlı fark yoktu (sırasıyla $\mathrm{p}=0.896$, $\mathrm{p}=0.357, \mathrm{p}=0.504, \mathrm{p}=0.179)$. mTESE’nin başarılı olduğu grupta ortalama testis hacmi anlamlı olarak daha yüksek olup, serum FSH ve LH düzeyleri anlamlı olarak düşüktü (sırasıyla p=0.029, p=0.004, $\mathrm{p}=0.001$ ). Histopatolojik değerlendirmede mTESE başarısı açısından hipospermatogenez, sertoli cell only sendromu (SCOS) ve matürasyon arresti (MA) grupları arasında anlamlı fark bulundu (sırasıla\% 88.5, \%37.5, \% 30; $\mathrm{p}<0.001)$.Sonuç: Tek taraflı mTESE başarı oranımız, daha önce bildirilen bilateral serilerle benzer olarak bulundu. mTESE başarısını etkileyen birden çok prediktif faktör bulunmakla birlikte, tek taraflı mTESE uygulamasının daha az invaziv olması ve kontralateral testis bütünlüğünün korunması nedeniyle kurtarma mTESE açısından avantaj sağlayabilir.

Anahtar Kelimeler: Non-obstrüktif azoospermia, Mikro-TESE, Sperm elde etme, unilateral
Abstract

Objective: We aimed to present the results of unilateral microscopic testicular sperm extraction (mTESE) in non-obstructive azoospermia (NOA) cases in our clinic and to elucidate the factors affecting mTESE success.

Materials and Methods: Our study was prospectively designed and 102 NOA patients were included. Testis volumes, serum follicle stimulating hormone (FSH), luteinizing hormone (LH), prolactin (PRL) and testosterone (T) levels were measured and genetic evaluations was carried out. We performed mTESE and divided patients into two groups according to sperm extraction results as MTESE is successful (sperm could be found) or failed (sperm could not be found). The two groups were compared in demographic, clinical and histopathological data.

Results: Sperm extraction by mTESE was successful in $64(62.7 \%)$ patients. There was no significant difference between two groups in terms of age, infertility times, serum $\mathrm{T}$ and PRL levels $(\mathrm{p}=0.896$, $\mathrm{p}=0.357, \mathrm{p}=0.504, \mathrm{p}=0.179$, respectively). Serum FSH and LH levels were significantly lower, and the mean testis volume was significantly higher in the group that micro-TESE was successful ( $p=0.004$, $\mathrm{p}=0.001, \mathrm{p}=0.029$, respectively). Histopathological evaluation revealed a significant difference between hypospermatogenesis, sertoli cell only syndrome (SCOS) and maturation arrest (MA) groups in terms of mTESE success $(88.5 \%, 37.5 \%, 30 \%$, respectively; $\mathrm{p}<0.001$ ).

Conclusion: Our unilateral mTESE success rate was similar to those performed bilaterally in literature. Besides the multiple predictive factors of mTESE success rate, unilaterally performed mTESE is less invasive procedure preserving the integrity of the contralateral testis and may be advantageous in terms of improving salvage mTESE results.

Keywords: Non-obstructive azoospermia, Micro-TESE, Sperm retrieval, Unilateral. 


\section{INTRODUCTION}

Male infertility is defined as the absence of pregnancy within 12 months despite of unprotected sexual intercourse from normal vaginal route in presence of a normal female partner. Its estimated worldwide prevalence is $10-15 \%$. The underlying etiology of infertility in $10-15 \%$ of infertile males and $1 \%$ of general population has been azoospermia $(1,2)$. Azoospermia is investigated in two subgroups; obstructive azoospermia (OA) and non-obstructive azoospermia (NOA).

NOA patients constitute $60 \%$ of the azoospermia patients (3). The etiology of NOA includes translocations and microdeletions in $\mathrm{Y}$ chromosome, cryptorchidism, testicular torsion, radiation, toxins, varicocele and idiopathic causes $(4,5)$.

Despite the absence of spermatozoa in the ejaculate of the NOA patients, sperm retrieval may still be possible due to the presence of isolated active spermatogenesis foci. The use of assisted reproductive techniques is essential for the conception (6).

Microscopic testicular sperm extraction (mTESE) was first described by Shlegel and Li in 1999 (7), and have become the most preferred technique for sperm retrieval in NOA patients. The procedure has low complication rates, and high success rates ranging from $35 \%$ to $75 \%$ (7-13).

Although mTESE has very low complication rates, it is an invasive procedure. When applied to both testes, it may result in damage to bilateral testes, decrease in testicular volume, deterioration of testicular blood flow, and decreased testosterone level (14).In our clinic, we perform mTESE unilaterally in this respect. In this study, we aimed to present our unilaterally performed micro-TESE results and the factors affecting the success of the procedure.

\section{MATERIAL AND METHODS}

Our study was prospectively designed. One hundred and two NOA patients who applied to Erzurum Atatürk University Faculty of Medicine Research Hospital, In Vitro Fertilization (IVF) Center, between June 2013 and 2015, for assisted reproductive techniques were included. Demographic data and clinical evalua- tion results of the patients were recorded.

Testis volume was measured by Prader orchidometer. Three semen samples were taken from the patients with intervals of 15 days and after at least 3 and no more than 5 days of sexual abstinence. Semen analysis was carried out by the biologist and evaluated according to the World Health Organization criteria. Serum follicle stimulating hormone (FSH), luteinizing hormone (LH), prolactin (PRL) and testosterone (T) levels of patients were measured from blood samples taken between 08:00 and 10:00 in the morning.

Karyotype analysis and Y chromosome microdeletions were genetically investigated for all patients.

mTESE was unilaterally performed in all patients by the same surgical team and to the larger sized testis which have better consistency. The procedure was performed under general anesthesia. The testis was taken out with approximately $5 \mathrm{~cm}$ one sided incision parallel to the raphe. First of all, microsurgery epididymal sperm aspiration (MESA) was performed in all patients. If the sperm retrieval was failed in MESA; a wide incision was made on tunica albuginea under microscopic examination, closer to the mid-section of the testis and free from vessels. Approximately 10 bright, white and wide tubules were selected and collected with micropenset under 20-25X optical magnification. A biopsy specimen was taken intraoperatively for histopathological diagnosis. The tissue samples taken from all the patients were evaluated by the same embryologist and the same pathologist.

Patients were divided into two groups according to sperm extraction results as mTESE is successful (sperm could be found) (group 1) or failed (sperm could not be found) (group 2). The two groups were compared in terms of age, testis volumes, serum T, LH, FSH and PRL levels, karyotype analysis, AZF microdeletions and testicular histopathology.

Verbal and written informed consents were taken from all of the patients. The study was conducted in accordance with the Declaration of Helsinki and approved by the Ethics Committee of Erzurum Atatürk University Faculty of Medicine (19.02.2015, \#29). 
Table 1: mTESE success rate, demographic data, clinical features and biochemical analyses.

\begin{tabular}{|c|c|c|c|}
\hline Variables & $\begin{array}{c}\text { Sperm (+) } \\
(\text { Group 1) } \\
(n=64)\end{array}$ & $\begin{array}{c}\text { Sperm (-) } \\
\text { (Group 2) } \\
(\mathbf{n}=\mathbf{3 8})\end{array}$ & $\mathbf{p}$ \\
\hline Age (year) Mean $\pm S D$ & $34.7 \pm 5.68$ & $35 \pm 7.56$ & 0.896 \\
\hline Infertility time (year) Mean $\pm S D$ & $6 \pm 3.87$ & $6.4 \pm 3.73$ & 0.357 \\
\hline Testis volume $(\mathrm{ml})$ Mean $\pm S D$ & $16.97 \pm 5.16$ & $14.50 \pm 5.19$ & $0.029^{*}$ \\
\hline $\mathrm{T}(n g / m l) M e a n \pm S D$ & $2.96 \pm 1.08$ & $3.15 \pm 1.3$ & 0.504 \\
\hline PRL $(n g / m l) M e a n \pm S D$ & $8.11 \pm 4.07$ & $9.85 \pm 5.11$ & 0.179 \\
\hline FSH (mIU/ml) Median (Min-Max) & $12.15(64.7-0.48)$ & $23.85(67.6-0.97)$ & $0.004^{*}$ \\
\hline LH (mIU/ml) Median (Min-Max) & $5.66(28.2-0.28)$ & $10.10(22.5-0.46)$ & $0.001^{*}$ \\
\hline mTESE success rate (\%) & 62,7 & - & - \\
\hline
\end{tabular}

${ }^{*} \mathrm{p}<0.05$ is statistically significant.

LH: Luteinizing hormone, FSH: Follicle stimulating hormone, PRL: Prolactin,

$\mathrm{T}$ : Testosterone, mTESE: micro testicular sperm extraction,

SD: Standard deviation, Min-Max: Minimum-Maximum.

Table 2: Comparison of the groups in terms of histopathological diagnoses.

\begin{tabular}{|l|c|c|c|}
\hline $\begin{array}{l}\text { Histopathological } \\
\text { Diagnoses }\end{array}$ & $\begin{array}{c}\text { Sperm Retrieval } \\
(+) /(-)\end{array}$ & $\begin{array}{c}\text { Number of Patients } \\
(n)\end{array}$ & $\begin{array}{c}\text { Sperm Retrieval Rate } \\
(\%)\end{array}$ \\
\hline \multirow{2}{*}{ Hypospermatogenesis a } & $(+)$ & 46 & 88,5 \\
\cline { 2 - 4 } & $(-)$ & 6 & 11,5 \\
\hline \multirow{2}{*}{ SCOS ${ }^{\text {b }}$} & $(+)$ & 15 & 37,5 \\
\hline \multirow{2}{*}{ MA $^{\mathrm{c}}$} & $(-)$ & 25 & 62,5 \\
\cline { 2 - 4 } & $(+)$ & 3 & 30 \\
\hline
\end{tabular}

${ }^{*} \mathrm{p}<0.05$ is statistically significant.

SCOS: Sertoli Cell Only Syndrome, MA: Maturation arrest

Sperm retrieval rates between ${ }^{\mathrm{a}}$ and ${ }^{\mathrm{b}}$ was significantly different; $\mathrm{p}<0.001^{*}$.

Sperm retrieval rates between ${ }^{\mathrm{a}}$ and ${ }^{\mathrm{c}}$ was significantly different; $\mathrm{p}<0.001^{\star}$.

$(+)=$ sperm was found in micro-TESE.

$(-)=$ sperm was not found in micro-TESE.

\section{Statistical Analyses}

Statistical analysis was carried out by using the SPSS software version 20 (SPSS Inc., Chicago, IL). Numerical variables were investigated using visual (histograms, probability plots) and analytical methods (Kolmogorov-Smirnov test) to determine whether or not they are normally distributed. Independent groups Student $\mathrm{T}$ test was used in normally distributed numerical variables and analyses were presented using means and standard deviations. Mann-Whitney U test was used in the analysis of numerical variables that were not normally distributed variables and the analyses were presented using medians, and minimum and maximum values. Categorical data were expressed as number and percentages. Chi-square test was used in the comparing categorical variables between the two groups. Bonferroni corrected Mann-Whitney U test was performed to identify the groups from which the difference was derived when there were significant results among multiple groups. An overall 5\% type-1 error level was used to infer statistical significance.

\section{RESULTS}

Serum FSH and LH levels were significantly lower and mean testis volume was significantly higher in group 1 ( $\mathrm{p}=0.004, \mathrm{p}=0.001, \mathrm{p}=0.029$, respectively). There was no significant difference in terms of the 
age, infertility time, serum $\mathrm{T}$ and PRL levels of sperm between group 1 and group $2(\mathrm{p}=0.896, \mathrm{p}=0.357$, $\mathrm{p}=0.504, \mathrm{p}=0.179$, respectively). mTESE success rate was found as $62.7 \%$ (Table 1 ).

Histopathological examinations of the biopsies taken during mTESE were reported as hypospermatogenesis, sertoli cell only syndrome (SCOS) and maturation arrest (MA). There was a significant difference between hypospermatogenesis, SCOS and MA groups (88.5\%, $37.5 \%, 30 \%$, respectively; $\mathrm{p}<0.001)$. In the bilateral comparisons, this difference was found to be due to the difference between hypospermatogenesis-SCOS and hypospermatogenesis-MA groups $(\mathrm{p}<0.001)$ (Table 2$)$.

In our study, 4 patients were given 6 months of human chorionic gonadotropin (HCG) hormonotherapy before salvage mTESE. In 1 of 4 patients, sperm could be found in salvage mTESE. However, statistical evaluation was not possible due to the number of patients.

Non-mosaic Klinefelter syndrome (KS) was detected in 9 and AZFc microdeletion was detected in 3 of the patients included in our study. mTESE was successful in 3 of 9 patients who had KS, and in 3 of the patients who had AZFc microdeletion. Six of the patients included in our study had a history of orchiopexy due to cryptorchidism with 4 of them bilaterally and 2 of them unilaterally operated. We performed mTESE contralaterally in patients with unilateral orchiopexy history. mTESE was successful in 2 of the patients with bilateral orchiopexy and 1 of the patients with unilateral orchiopexy history.

Grade III varicocele was diagnosed in 5 patients and subinguinal microscopic varicocelectomy was performed. After the varicocelectomy, patients were re-diagnosed with azoospermia, and then MTESE was performed. mTESE was successful in all of these 5 patients.

In our study, we did not experience severe complications such as epididymitis, scrotal hematoma or testicular hydrocele.

\section{DISCUSSION}

mTESE is usually performed bilaterally and performed in counter testis if sperm could not be found in one testis. In literature, bilaterally performed mTESE success rates were found between 35-75\% (7-13). Our mTESE success rate as high as $62.7 \%$ have been supportive for unilateral mTESE.

Decreased testis volume is known to be associated with hypogonadism. Okada et al. found at least $2 \mathrm{ml}$ decrease in mean testis volume in $25 \%$ of conventional TESE and $2.5 \%$ in mTESE 6 months after the surgery through 120 patients, and it was thought to be related with the amount of tissue removed during the procedure (15). Ozturk et al. reported a $0.3 \mathrm{ml}$ and $0.6 \mathrm{ml}$ decrease in mean testis volume 3 and 12 months after mTESE, respectively. It was thought to be related with the testicular tissue extraction leading to impaired blood supply (16).

Increased amount of the removed testicular tissue results in impaired testosterone secretion due to the decrease in Leydig cell number. In a meta-analysis, the mean serum total testosterone level was shown as profoundly decreased after mTESE in men with NOA (17). Even though the complication rate of MTESE is generally low, unilateral surgery is less invasive than bilateral which may lead to achieve lower complication rates with less surgical load. The tissue integrity of the contralateral testis has not been compromised in unilateral surgery and this may increase the success rate of salvage mTESE.

In our study design, we planned salvage mTESE for contralateral testis after 3-6 months of hormonal manipulation. However, only 4 of the patients could come back to our clinic for a variety of reasons, such as the desperation of patients, anxiety of patients about the surgery, and due to the fact that patients living in remote areas could not come back to the hospital. We have been able to perform salvage mTESE in only 4 of the 38 patients in whom we could not find sperm in MTESE. Therefore, we did not have the chance to evaluate the advantage of unilateral mTESE in terms of salvage procedure. In further studies, the evaluation of salvage mTESE results may provide valuable information in comparison of the unilateral mTESE with bilateral.

It has been shown in previous studies that elevating 
the serum T level above $300 \mathrm{ng} / \mathrm{dL}$ threshold by hormonotherapy with hCG, tamoxifen, clomiphene citrate or aromatase inhibitors provide $20-30 \%$ increase in sperm retrieval rate $(12,13,17,18)$. However, Ramasamy et al. found no significant relationship between the low and normal T levels and mTESE success rate (19). Our study supported this data. However, intratesticular testosterone (ITT) level is thought to be predictive of mTESE success. It is controversial whether the optimization of serum $\mathrm{T}$ level before mTESE significantly increases mTESE success rate or not $(12,17,19)$.

In our study, the testis volume was significantly higher in the group that mTESE was successful. Although there is a positive correlation between testis volume and mTESE success, testis volume is thought as not to be a consistent parameter in terms of predictive value $(20,21)$. The small testis volume is not a contraindication for mTESE. Besides, testis volume may be normal in the presence of early or late MA histology in NOA patients (20).

There is no reference serum FSH level that indicates whether spermatogenesis is normal or not, however previous studies have shown that sperm retrieval is less successful in azoospermic patients with elevated serum FSH level (8-10). Our study was consistent with previous reports in terms of significantly lower level of FSH in the group that mTESE was successful. On the other hand, high level of FSH does not always reflect the absence of sperm containing seminiferous tubules (11). The FSH level is inversely proportional to the total germ cell number in the testis, but it is not directly related with the later stages of spermatogenesis and its predictive value is controversial $(2,3)$.

Five patients had grade III varicocele and we performed subinguinal microscopic varicocelectomy. Six months after the varicocelectomy, azoospermia was detected again in semen analysis. Therefore, mTESE was applied and sperm was found in all of them. Previous studies have shown that varicocelectomy provides $10 \%$ increase in the success of MTESE, however some studies showed no significant effect. The general view is towards varicocelectomy $(3,22,23)$.

The histopathological diagnosis is an independent strong predictive parameter of mTESE success (24-27). mTESE success rate increases up to $90 \%$ in case of positive spermatozoa in preoperative biopsy. In particular, the presence of mature spermatozoa in biopsy is an important positive predictor $(2,27,28)$. Similarly, histopathological diagnosis which has been reported in previous surgery(s) for sperm extraction is an important predictor for the success of the subsequent sperm retrieval procedure. Histopathological diagnosis of hypospermatogenesis significantly increases and SCOS significantly decreases the chances to achieve success $(2,29)$. Okada et al. reported their sperm retrieval rate as $100 \%, 75 \%$ and $33.9 \%$ in hypospermatogenesis, MA and SCOS, respectively (15). Similar rates have been reported in subsequent studies $(2,21,30)$. Our highest sperm retrieval success rate of mTESE was also in hypospermatogenesis.

\section{CONCLUSION}

Our unilateral mTESE success rate was similar to those performed bilaterally in literature. Unilateral MTESE is less invasive procedure preserving the integrity of the contralateral testis. This may be advantageous in terms of improving the decrease in testosterone level and testis volume after the procedure, and increasing the salvage mTESE success rate. A parameter predicting mTESE success rate alone has not been found yet. Therefore, using a combination of multiple variables may guide the surgeon for better surgical evaluation and better meet expectations of infertile couples.

\section{REFERENCES}

1. Goktolga U, Izetbegovic S, Rama A, Spahovic H, Goktas C. The First Report from Bosnia and Herzegovina on Micro-tese Results in Azoospermic Patients. Med Arch 2015; 69:196-9.

2. Abdel Raheem A, Garaffa G, Rushwan N, et al. Testicular histopathology as a predictor of a positive sperm retrieval in men with non-obstructive azoospermia. BJU Int 2013; 111:492-9

3. Bernie AM, Ramasamy R, Schlegel PN. Predictive factors of successful microdissection testicular sperm extraction. Basic Clin Androl 2013;23:5.

4. Raman JD, Schlegel PN. Testicular sperm extraction with 
intracytoplasmic sperm injection is successful for the treatment of nonobstructive azoospermia associated with cryptorchidism. J Urol 2003; $170: 1287-90$.

5. Jarow JP, Espeland MA, Lipshultz LI. Evaluation of the azoospermic patient. J Urol 1989; 142:62-5.

6. Esteves SC, Miyaoka R, Agarwal A. An update on the clinical assessment of the infertile male. Clinics (Sao Paulo) 2011; 66:691-700.

7. Schlegel PN. Testicular sperm extraction: microdissection improves sperm yield with minimal tissue excision. Hum Reprod 1999; 14:131-5.

8. Zitzmann M, Nordhoff V, von Schonfeld V, et al. Elevated follicle-stimulating hormone levels and the chances for azoospermic men to become fathers after retrieval of elongated spermatids from cryopreserved testicular tissue. Fertil Steril 2006; 86:339-47.

9. Ramasamy R, Lin K, Gosden LV, et al. High serum FSH levels in men with nonobstructive azoospermia does not affect success of microdissection testicular sperm extraction. Fertil Steril 2009; 92:590-3.

10. Aydos K, Unlu C, Demirel LC, Evirgen O, Tolunay O. The effect of pure FSH administration in non-obstructive azoospermic men on testicular sperm retrieval. Eur J Obstet Gynecol Reprod Biol 2003; 108:54-8.

11. Tsujimura A. Microdissection testicular sperm extraction: prediction, outcome, and complications. Int J Urol 2007; 14:883-9.

12. Shinjo E, Shiraishi K, Matsuyama H. The effect of human chorionic gonadotropin-based hormonal therapy on intratesticular testosterone levels and spermatogonial DNA synthesis in men with non-obstructive azoospermia. Andrology 2013; 1:929-35.

13. Kato Y, Shiraishi K, Matsuyama H. Expression of testicular androgen receptor in non-obstructive azoospermia and its change after hormonal therapy. Andrology 2014; 2:734-40.

14. Eliveld J, van Wely M, Meißner A, et al. The risk of TESEinduced hypogonadism: a systematic review and meta-analysis. Human reproduction update, 2018; 24:442-454.

15. Okada H, Dobashi M, Yamazaki T, et al. Conventional versus microdissection testicular sperm extraction for nonobstructive azoospermia. J Urol 2002; 168:1063-7.

16. Ozturk U, Ozdemir E, Dede O, et al. Assessment of antisperm antibodies in couples after testicular sperm extraction. Clin Investig Med 2011; 34: 179 - 184.

17. Hussein A, Ozgok Y, Ross L, Rao P, Niederberger C. Optimization of spermatogenesis-regulating hormones in patients with non-obstructive azoospermia and its impact on sperm retrieval: a multicentre study. BJU Int 2013; 111:E110-4.

18. Shiraishi K, Ohmi C, Shimabukuro T, Matsuyama H. Human chorionic gonadotrophin treatment prior to microdis- section testicular sperm extraction in non-obstructive azoospermia. Hum Reprod 2012; 27:331-9.

19. Reifsnyder JE, Ramasamy R, Husseini J, Schlegel PN. Role of optimizing testosterone before microdissection testicular sperm extraction in men with nonobstructive azoospermia. J Urol 2012; 188:532-6.

20. Bryson CF, Ramasamy R, Sheehan M, et al. Severe testicular atrophy does not affect the success of microdissection testicular sperm extraction. J Urol 2014; 191:175-8.

21. Kalsi J, Thum MY, Muneer A, Abdullah H, Minhas S. In the era of micro-dissection sperm retrieval (m-TESE) is an isolated testicular biopsy necessary in the management of men with non-obstructive azoospermia? BJU Int 2012; 109:418-24.

22. Matthews GJ, Matthews ED, Goldstein M. Induction of spermatogenesis and achievement of pregnancy after microsurgical varicocelectomy in men with azoospermia and severe oligoasthenospermia. Fertil Steril 1998; 70:71-5.

23. Schlegel PN, Kaufmann J. Role of varicocelectomy in men with nonobstructive azoospermia. Fertil Steril 2004; 81:1585-8.

24. Jezek D, Knuth UA, Schulze W. Successful testicular sperm extraction (TESE) in spite of high serum follicle stimulating hormone and azoospermia: correlation between testicular morphology, TESE results, semen analysis and serum hormone values in 103 infertile men. Hum Reprod 1998; 13:1230-4.

25. Sousa M, Cremades N, Silva J, et al. Predictive value of testicular histology in secretory azoospermic subgroups and clinical outcome after microinjection of fresh and frozenthawed sperm and spermatids. Hum Reprod 2002; 17:180010 .

26. Su LM, Palermo GD, Goldstein M, et al. Testicular sperm extraction with intracytoplasmic sperm injection for nonobstructive azoospermia: testicular histology can predict success of sperm retrieval. J Urol 1999; 161:112-6.

27. Tournaye H, Verheyen G, Nagy P, et al. Are there any predictive factors for successful testicular sperm recovery in azoospermic patients? Hum Reprod 1997; 12:80-6.

28. Schoor RA, Elhanbly S, Niederberger CS, Ross LS. The role of testicular biopsy in the modern management of male infertility. J Urol 2002; 167:197-200.

29. Kalsi JS, Shah P, Thum Y, et al. Salvage micro-dissection testicular sperm extraction; outcome in men with non-obstructive azoospermia with previous failed sperm retrievals. BJU Int 2015; 116:460-5.

30. Seo JT, Ko WJ. Predictive factors of successful testicular sperm recovery in non-obstructive azoospermia patients. Int J Androl 2001; 24:306-10. 